\title{
COMPARING DUTCH AND BRITISH HIGH PERFORMING MANAGERS
}

\author{
André A. de $\mathrm{Waal}^{12} *$ \\ Béatrice I.J.M. van der Heijden ${ }^{345}$ \\ Denny Meyer ${ }^{6}$ \\ Christopher Selvarajah ${ }^{6}$ \\ ${ }^{1}$ Maastricht School of Management, the Netherlands, andredewaal@planet.nl \\ ${ }^{2}$ Center for Organizational Performance, the Netherlands \\ ${ }^{3}$ Radboud University Nijmegen, the Netherlands \\ ${ }^{4}$ Open University of the Netherlands \\ ${ }^{5}$ University of Twente, the Netherlands \\ ${ }^{6}$ Swinburne University of Technology, Melbourne, Australia \\ * Corresponding author
}

TRACK: LEADERSHIP

Keywords: high performing managers, the Netherlands, the UK 


\section{COMPARING DUTCH AND BRITISH HIGH PERFORMING MANAGERS}

National cultures have a strong influence on the performance of organizations and their influence should be taken into account when studying the traits of High Performing Managers (HPMs). At the same time, many studies that focus upon the attributes of successful managers show that, notwithstanding the fact that national culture does affect these attributes, there are attributes that are similar for managers across countries. This article reports on empirically validated profiles of Dutch and British HPMs in one sector, being Information and Communication Technology (ICT), by applying a cross-cultural framework to a sample of managers from the Netherlands and the UK. Subsequently, based on the profiles, the similarities and differences in attributes for managerial success between Dutch and British HPMs are identified. The practical implication of the research is that multinational companies have to take the differences in attributes into account when training their managers for oversees assignments. 


\section{INTRODUCTION}

According to Lee and Yu (2004), and Kirkman et al. (2006), national cultures have a strong influence on the performance of organizations, and bring about different determinants of high performance, in terms of the traits, attitudes, and behaviors that people see as valuable (Sparrow and Hiltrop, 1997; Iguisi, 2009). Culture has been described as "something to do with the people and the unique quality and style of organization" (Kilmann et al., 1985, p. 11) or "the way we do things around here" (Deal and Kennedy, 1982, p. 12). A frequently used definition is the one by Hofstede (2001): 'The collective programming of the mind that distinguishes one group or category of people from another'. Hoecklin (1995) stated that there is an intimate relationship between national culture and organizational culture; and asserted that companies cannot develop an organizational culture that does not incorporate, substantially, the prevailing cultural factors of the country in which it operates. Merchant and Van der Stede (2003) argued that national culture has a direct effect on organisational performance because it can cause organizational members to react differently on similar performance information. Therefore, national culture appears to be a relevant factor for the performance of organizations, and its influence should be taken into account when studying the traits of High Performing Managers (HPMs) (Gerstner and Day, 1994; Gabrielson et al., 2009).

At the same time, many studies that focus upon the attributes of successful managers show that, notwithstanding the fact that national culture does affect these attributes, there are attributes that are similar for managers across countries (Dickson et al., 2003). The Globe project (Den Hartog et al., 1999) reported that in all countries participating in the project, outstanding managers were perceived by participating middle managers to be encouraging, motivational, dynamic and have foresight. Ineffective managers were seen to be noncooperative, ruthless and dictatorial. The outcomes of the study by House et al. (1997) indicated that there are some leader attributes and behaviours that are universally accepted and considered effective, regardless of the specific national culture.

Brodbeck et al. (2000) studied the cultural variation of leadership prototypes across 22 European countries, and found that, for virtually all European countries, leadership attributes that were assumed by participating middle managers to be important for success included being inspirational, having vision and integrity, being performance-oriented, being decisive, and being a team integrator. Being self-centred and malevolent was perceived as detrimental for being an effective leader. In a similar vein, in a study among US and European managers, Robie et al. (2001) found that a drive for results and analysing issues effectively were the best predictors for effective managerial performance. Lesley and Van Velsor (1998) found that US and European managers perceive managerial effectiveness as having personal influence, being cooperative, and accepting rules and procedures set by an external authority.

Other researchers, like Dorfman et al. (1997), Boehnke (1999), Juhl et al. (2000), Mehta et al. (2001), Silverthorne (2001), Matic (2008), Zagorsek et al. (2004), and Bret Becton and Field (2009), also reported common attributes among effective managers in diverse cultures. A possible explanation, for this similarity in outcomes, was proposed by Hazucha et al. (1999) as they hypothesized that, as the nature of managerial work tends to be similar across countries, the attributes to be successful in managerial work converge to similarity. Analogously, Taras et al. (2009) remarked that specific attributes linked to national culture might become obsolete as in today's global village geographical boundaries are becoming less relevant, and could therefore be less useful as denominators. Zagorsek et al. (2004, p. 31) even concluded: "Culture does matter. But its impact is not as strong as is commonly thought. Maybe the world is actually becoming a 'global village' after all." Den Hartog et al. (1999), however, warned that, although the leader attributes that are assumed to 
be important can be similar for different cultures, the perceived importance of these attributes can vary across cultures.

This article aims to further the research into common attributes for managerial success. More specifically, it reports on empirically validated profiles of Dutch and British HPMs in one sector, being Information and Communication Technology (ICT), by applying a cross-cultural framework to a sample of managers from the Netherlands and the UK. Subsequently, based on the profiles, the similarities and differences between Dutch and British HPMs are identified. The article is organized as follows. In the next section the crosscultural research framework that formed the basis of our study is introduced (De Waal et al., 2010). Then, using the cultural frameworks from Hofstede (1989), and the ones used in the Globe project (House et al., 2004), hypotheses focusing on the similarities and differences between Dutch and British HPMs are presented. These hypotheses have been tested using a sample of responses from managers from the Netherlands and the UK. The article ends with a discussion section comprising a reflection upon the outcomes, an outline of the limitations of the research and recommendations for further study, and some practical implications.

\section{THE FRAMEWORK OF EXCELLENT LEADERSHIP}

In order to identify the characteristics of HPMs, the framework of Excellent Leadership by Selvarajah et al. (1995) was chosen, because this framework is based on a multicultural approach, and because it has both etic and emic traits (Jayakody, 2008). The etic approach argues that leadership theories are universal while the emic approach claims that these are culture - or context-specific (Jayakody, 2008). Instead of the terms etic and emic, Morrison (2000) used the terms generalizable and idiosyncratic. Another variation in terminology is suggested by Marcoulides et al. (2004) who referred to the rationalist and culturalist views, and indicated that leadership practices depend on sector developments, as well as on the uniqueness of a country's culture.

Selvarajah et al.'s framework is based upon the assumption that there are leadership factors that are universal (etic), but that these factors are manifested in various overt behaviours, which depend on the cultural (emic) context, thus sidestepping the etic-emic dilemma (Javidan \& Carl, 2004; Jong et al., 2009; Smith et al., 1989). The purpose of the study by Selvarajah et al. (1995) was to develop factors or dimensions which clustered behavioural values in national and sub-national groups. For this aim, they developed 94 'excellence in leadership' value statements. In their theoretical framework, 'excellence' is defined as "surpassing others in accomplishment or achievement" (Taormina and Selvarajah, 2005, p. 300), and the concept is operationalized and examined in terms of behaviours exhibited by someone in a managerial position, rather than in terms of personal traits or personal characteristics, as the latter are difficult to observe (Selvarajah and Meyer, 2008).

The statements were formulated based on an in-depth study of relevant literature on leadership and management excellence, both from a Western (Bennis, 1983, 1989a, 1989b; Bennis and Nanus, 1985; Burns, 1978, 1984; Hollander, 1978; Hunt and Larson, 1979; Kantor, 1985; Peters and Waterman, 1983; Prigogine, 1984; Rost, 1991; Stogdill and Coons, 1957; Takala, 1998; Yukl, 1989), and from an Eastern perspective (Bedi, 1990; Ling, 1989; Ling et al., 1992; Misumi, 1984; Mukhi, 1989; Pascale and Athos, 1981; Sinha, 1980; Srivastava, 1983; Swierczek, 1991; Xu et al., 1985). Subsequently, a group of researchers from six Asian countries (Brunei, Indonesia, Malaysia, Philippines, Singapore, and Thailand) explored the statements with the objective of categorising them within broader dimensions, expressing a balanced international perspective, rather than using instruments developed for a Western culture only. The five broader dimensions that were identified were: (1) Excellent 
Leadership; (2) Personal Qualities; (3) Managerial Behaviours; (4) Organisational Demands; and (5) Environmental Influences (see Selvarajah et al, 1995).

Excellent Leadership describes the combination of behaviours and attitudes that are desirable and required for good leadership within a certain cultural context (Selvarajah, 2008). Personal Qualities are the personal values, skills, attitudes, behaviour and qualities of an individual, and emphasise morality, religion, inter-personal relationships, and communication. Managerial Behaviours cover a person's nature, values, attitudes, actions and styles when performing managerial duties. They emphasise persuasive powers. Organizational Demands are the ways a manager responds to the goals, objectives, structures and issues in an organisation, and emphasise the importance of organisational prosperity. Environmental Influences are external factors that influence the success of the entire organisation. They emphasise the importance of scanning and evaluating the external environment for opportunities. The conceptual framework for the study of excellent leadership is illustrated in Figure 1 (Selvarajah et al., 1995).

\section{INSERT FIGURE 1 ABOUT HERE}

The 94 'Excellence in Leadership' value statements that were developed by Selvarajah et al. (1995) were subjected to a Q-sort technique (Kerlinger, 1973), using the above five dimensions as the framework for categorization. This was performed by a sample of Asian managers who were attending executive programs at the Asian Institute of Management in Manila, and at the Vocational Technical Institute (VOC-TECH), the Southeast Asian Management Education Organisation (SEAMEO) institute located in Brunei Darussalam.

For the Q-sort technique, all statements were each printed three times on small cards, and the managers were asked to sort the resulting sets of cards in three different ways. The first sorting was used to determine the order of importance of each statement in the light of excellence in leadership. The second sorting was used to determine to which of the four dimensions each statement belonged, and the third sorting was used to determine the importance of each statement in terms of its chosen dimension (i.e., the importance of each statement in proportion to the other statements assigned to the same dimension).

The relationships between the 94 statements, and the specific structure of the summated scales calculated for the five dimensions, vary depending on the cultural context in which the managers are working. Therefore, the construction of each dimension differs across countries, and provides cultural insights into leadership behaviours, and values in various countries, as illustrated by Taormina and Selvarajah (2005), Selvarajah and Meyer (2007, 2008), and Selvarajah (2008). In this article, we have exactly used the approach as explained above, and we expect the individual items assigned to each dimension to reflect both the Dutch and English contexts.

\section{HYPOTHESES' DEVELOPMENT}

In this section, the hypotheses that will be tested using the framework of Selvarajah et al. (1995) are given. The hypotheses are based on the cultural frameworks from Hofstede (2001), and the Globe project (House et al. 2004). However, before we can move towards the hypotheses' tests, the general assumption underlying our study has to be tested, that is, whether HPMs in the Netherlands and the UK can be described using the framework of Excellent Leadership developed by Selvarajah et al. (1995). This gives rise to the first Hypothesis: 
H1. A five-dimensional factor structure consisting of the dimensions of Excellent Leadership, Managerial Behaviours, Environmental Influences, Personal Qualities and Organisational Demands is valid to describe Dutch and British HPMs.

For the other hypotheses, the dimensions of Hofstede (2001) and House et al. (2004) are used, in a similar way as Suutari (1996) did. To distinguish between national cultures, Hofstede formulated four dimensions, or distinguishing characteristics, and later added a fifth dimension (long-term orientation) which was assumed to be valid to distinguish the difference in thinking between the East and the West (Hofstede et al., 2002). The initial four dimensions were: (1) uncertainty avoidance, which refers to the extent to which people in a society feel comfortable with ambiguity and uncertainty; (2) individualism versus collectivism, which refers to the extent to which one's identity is derived from one's self as opposed to the group of which the individual is a member; (3) power distance, which refers to the extent to which members of a society accept that institutional power is distributed unequally; and (4) masculinity versus femininity, being the extent to which the social gender roles in a society are clearly masculine (assertive and hard) or feminine (equality, solidarity, and consensus). Hofstede (2001), in his book Cultures' Consequences, reported the results for the Netherlands for the first four dimensions on a scale ranging from 0 to 100: masculinity versus femininity (14), power distance (38), uncertainty avoidance (53), and individualism versus collectivism (80). These results suggest a more feminine-oriented society with a relatively low power distance, medium uncertainty avoidance, and a highly individualistic culture. Hofstede (2001) also fed back the scores for the UK: masculinity versus femininity (66), power distance (35), uncertainty avoidance (35), and individualism versus collectivism (89). These results suggest a more masculine-oriented society with a relatively low power distance, low uncertainty avoidance, and a highly individualistic culture.

In a feminine-oriented culture like the Netherlands, it is not possible that a manager evaluates the performance of an employee without taking into account the well-being of the person concerned, and there is a strong drive to avoid conflicts by striving for consensus and being a team player. In contrast, in a masculine-oriented culture like the UK, managers are more decisive, assertive, aggressive and competitive. They resolve conflicts by denying them or fighting them until "the best man" wins (Hofstede, 2001, p. 318). This gives the following Hypothesis:

H2. Value statements which emphasise managers' respect for their employees are more important for the Netherlands, which is characterized by a rather feminine culture, than for the UK, which is characterized by a rather masculine culture.

In a society with a low power distance, such as the Netherlands and the UK, creating an egalitarian society with equality between people is necessary, as managers and employees are basically considered equal. Subordinates expect to be consulted because their opinions should be regarded as important by the management (Hofstede, 2001, p. 108). This suggests the next Hypothesis:

H3. Value statements which emphasise managers' drive for consensus are equally important for the Netherlands and the UK, which are both characterized by a low amount of power distance.

The Netherlands score higher on the uncertainty avoidance dimension compared to the UK. This means that, according to Merchant and Van der Stede (2003), and Chong and Park 
(2003), compared to the UK, there is a stronger focus in the Netherlands on managers using elaborate formal planning systems with many procedures, rituals and targets, in order to diminish the uncertainty level of organizational members. These systems are expected to reduce the uncomfortable feelings people experience in unstructured situations (Hofstede, 2001, p. 169). This brings us to the following Hypothesis:

H4. Value statements which emphasise managers' preference for rules, procedures and formal systems are more important for the Netherlands, which is characterized by a medium level of uncertainty avoidance, than for the UK, which is characterized by a low level of uncertainty avoidance.

In individualistic cultures, such as the Netherlands and the UK, people are more selforiented rather than organisation-minded, individual initiative and individual decisionmaking is encouraged (McCoy et al., 2005), and individuals are supposed to look after themselves rather than to remain integrated into a group (Hofstede, 2001, p. 244). This gives the fifth Hypothesis:

H5. Value statements which emphasise managers' self-orientation are equally important for the Netherlands and the UK, which are both characterized by a highly individualistic culture.

Hofstede (2001) has indicated that his cultural framework is not a finished product but rather a base for further investigation. Several researchers, such as House and associates in the GLOBE project (Javidan and House, 2001; House et al., 2004), have responded to this call for more research, and have formulated nine dimensions that are aimed to distinguish between national cultures (House et al., 2004):

1. Assertiveness - The degree to which individuals are assertive, confrontational and aggressive in their relationship with others.

2. Collectivism I (institutional collectivism) - The degree to which organizational and societal institutional practices encourage and reward collective distribution of resources and collective action.

3. Collectivism II (in-group collectivism) - The degree to which individuals express pride, loyalty, and cohesiveness in their organizations or families.

4. Future orientation - The extent to which individuals engage in future-oriented behaviours such as delaying gratification, planning and investing in the future.

5. Gender egalitarianism - The degree to which a collective minimizes gender inequality.

6. Humane orientation - The degree to which a collective encourages and rewards individuals for being fair, altruistic, generous, caring and kind to others.

7. Performance orientation - The degree to which a collective encourages and rewards group members for performance improvement and excellence.

8. Power distance - The degree to which members of a collective expect power to be distributed equal.

9. Uncertainty Avoidance - The extent to which a society, organization, or group relies on social norms, rules and procedures to alleviate unpredictability of future events.

In House et al. (2004, Appendix B2), the scores for the Netherlands and the UK are listed, using a scale ranging from 1 to 7 (see Table I for the scale means).

INSERT TABLE I ABOUT HERE 
No additional hypotheses have been developed for power distance, collectivism and uncertainty avoidance as these have been addressed in Hypotheses 2 through 5. Neither has a hypothesis been developed for gender egalitarianism because, in our opinion, this has more to do with the number of female managers, and their position in society, than with the feminine orientation of a culture. However, for the remaining dimensions, additional hypotheses have been developed.

According to House et al. (2004), societies like the Dutch and the British one score higher on the assertiveness dimension, value dominant behaviour, have sympathy for the strong, value competition, try to have control over the environment, stress competition and performance, emphasize results over relationships, value taking initiative, and expect demanding and challenging targets. This leads us to the following Hypotheses:

H6. Value statements which emphasise the strength of managers are equally important for the Netherlands and the UK, which are both characterized by a fairly, highly assertive culture.

Societies such as the Dutch one that score higher on future orientation, are comprised of individuals who are more intrinsically motivated, and who are willing to learn continuously, and have organisations with a longer strategic orientation, which are more flexible and adaptive. These societies also value the deferment of gratification by placing a higher priority on long-term success, and emphasize visionary leadership that is capable of seeing patterns in chaos and uncertainty (House et al., 2004). This brings us to the following two Hypotheses:

H7. Value statements which emphasise managers' long-term orientation are more important for the Netherlands, which is characterized by a future-oriented culture, than for the UK, which is characterized by a less future-oriented culture.

H8. Value statements which emphasise the flexibility and adaptiveness of managers are more important for the Netherlands, which is characterized by a future-oriented culture, than for the UK, which is characterized by a less future-oriented culture.

In societies like the Dutch and the British ones, that score relatively high on humane orientation, others are important, values of altruism and generosity have high priority, personal and family relationships are important, and people are expected to promote paternalistic norms and relationships (House et al., 2004). This leads us to the following Hypotheses:

H9. Value statements which emphasise managers' ability to create a family-like organisational culture are equally important for the Netherlands and the UK, which are both characterized by a medium humane-oriented culture.

In societies like the Netherlands and the UK, that score higher on performance orientation, results are more emphasised than people, performance is rewarded, assertiveness and competitiveness are valued, giving feedback is seen as necessary for improvement, having a sense of urgency is important, and being direct and explicit in communications is valued (House et al., 2004) as well. Therefore, the last Hypothesis is formulated as follows:

H10. Value statements which emphasise direct and straight-forward communicating managers are equally important for the Netherlands and the UK, which are both characterized by a highly performance-oriented culture. 


\section{METHODOLOGY}

This study looked into the characteristics of Dutch and British HPMs, working at all managerial levels in an organisation. A managerial position is defined as a position in which the person has at least one subordinate. The research population in the Netherlands was approached through the Internet - in the period January to July 2009 - by means of the website of the largest management periodical in the Netherlands, Management Team, and through several organisations that were known to one of the authors. As the exact number of people invited to participate is unknown, the response rate can not be calculated. The research sample in the UK consisted of employees of ATLAS, a consortium of five ICT companies that were charged with improving the information and communication technology infrastructure of the British Ministry of Defence. Most of these employees were based in England.

In order to protect anonymity and to increase the response rate, neither the respondents nor their organisations were identified. A total of 808 usable questionnaires were filled out for the Netherlands, while 286 usable ones were filled out for the UK. The respondents were asked to rate the importance of each of the 94 statements from the framework of Excellent Leadership (Selvarajah et al., 1995) in the context of a successful manager, using an importance scale ranging from 1 (very unimportant) to 5 (very important). As such, the questionnaire explored perceptions of what good management should be (Laurent, 1983).

Of the Dutch respondents, 64\% were men and 34\% were women. $12.9 \%$ were younger than 35 years, $20.2 \%$ of the respondents was between the ages of 35 and 40, 19.9\% between 41 and $45,20.2 \%$ between 46 and 50,24.8\% between 51 and 55, none of the respondents were between the age of 56 and 60 , and $2.1 \%$ were over the age of 60 . Of the responding organisations, $59.7 \%$ were for-profit organisations, and $40.3 \%$ were not-for-profit ones, $10.3 \%$ were family-owned businesses, and $25 \%$ were quoted on the stock-market. The largest industry represented in the sample comprised education $(21.3 \%)$, followed by construction $(10.6 \%)$, professional services $(10.5 \%)$, government $(7.7 \%)$, financial services $(7.5 \%)$, production $(6.8 \%)$, accountancy $(5.3 \%)$, consultancy $(5.0 \%)$, healthcare - elderly care (4.8\%), healthcare - hospitals $(4.7 \%)$, Information \& Communication Technology $(4.5 \%)$, and others (11.3\%). Of the British respondents $85 \%$ were men and $15 \%$ were women $9.4 \%$ were younger than 35 years, $15.0 \%$ of the respondents was between the ages of 35 and 40 , $24.2 \%$ between 41 and $45,20.2 \%$ between 46 and 50, 18.2\% between 51 and 55, 10.1\% between 56 and 60, and $2.8 \%$ over the age of 60 . All of the respondents worked for for-profit companies within the ICT sector. There are significant differences between the Dutch and UK samples in terms of gender and age and this needs to be considered when interpreting the results. The higher percentage of women in the Dutch sample is particularly relevant.

\section{RESULTS}

The empirical validity of the framework suggested by Selvarajah et al. (1995) was tested by means of a Confirmatory Factor Analysis (CFA) (confirming the five distinguished dimensions) using AMOS version 17. In order to achieve a satisfactory fit, badly differentiating items for either country were removed from the original measurement instrument. According to Byrne (2001), the Root Mean Square Error of Approximation 
(RMSEA) should be less than .08, with goodness of fit indices (GFI and CFI) above 90 for both countries. The resulting scales showed acceptable reliability (Hair et al., 1998) with Cronbach alpha values above .60. This analysis served to support the first hypothesis. Invariance tests were then used to establish whether the same measurement model could be use for UK and Dutch managers for each of the five dimensions of the framework thereby testing the remaining hypotheses. The results given in Table II show a significant difference in the perceptions of leadership excellence for managers from the Netherlands and the UK (Chi-square $=13.10$, df $=5, \mathrm{p}=.022$ ), with UK managers giving more weight to the motivation of employees and continuing to learn how to improve performance than Dutch managers.

\section{INSERT TABLE II ABOUT HERE}

Environmental influences, such as economic circumstances, political situation, and cultural and legal factors, are external factors that influence the success of the organisation. Table III shows the loadings for this construct for UK and Dutch managers. There are no significant differences between these managers in terms of the weights for this construct (Chi-Square $=7.065, \mathrm{df}=4, \mathrm{p}=.132$ ).

\section{INSERT TABLE III ABOUT HERE}

Personal Qualities comprise the personal values, skills, attitudes, behaviour and qualities of an individual. As Table IV shows, the loadings are similar for managers from the UK and the Netherlands. There is no significant difference between the weights for these two sets of managers (Chi-Square $=7.566, \mathrm{df}=9, \mathrm{p}=.578)$.

\section{INSERT TABLE IV ABOUT HERE}

Managerial Behaviours entail a person's nature, values, attitudes, actions and styles which are shown to the outside world when performing managerial duties. There are significant differences between the measurement models for Dutch and UK managers (ChiSquare $=30.417, \mathrm{df}=9, \mathrm{p}<.001)$, with $\mathrm{UK}$ managers attributing more importance to delegation, persuading others to do things, and trusting those to whom work is delegated..

\section{INSERT TABLE V ABOUT HERE}

Organisational Demands relate to the way a manager responds to the goals, objectives, structures and issues in an organisation. There was no significant difference in the weights for the UK and Dutch managers as shown in Table VI (Chi-Square $=6.771, \mathrm{df}=5, \mathrm{p}=.238$ ), suggesting that UK and Dutch managers' perception of Organizational Demand is similar.

\section{INSERT TABLE VI ABOUT HERE}

In summary, the perceptions of managers from the UK and the Netherlands are similar in terms of Organisational Demand, Personal Qualities and Environmental Influence. However, there are significant differences in terms of Excellent Leader and Managerial Behaviour. UK managers attach more weight to 'employee motivation' and 'continuing to learn how to improve performance' as more important for an excellent leader than do Dutch managers. In addition UK managers consider three managerial behaviours to be more important than managers from the Netherlands. These three behaviours are 'trusting staff to do their jobs', 
'persuading others to do things' and 'delegation'. The significantly higher proportion of females in the Netherlands sample made it necessary for invariance tests also to be performed for gender, however no significant differences were found for the measurement models of men and women, suggesting that the above differences between the UK and the Netherlands cannot be attributed to gender differences. Invariance tests performed for age categories also showed no significant differences, so the mentioned differences between the two countries also cannot be attributed to age differences.

When scales were constructed for the five dimensions, a Multivariate Analysis of Variance showed that there were significant differences in the average scores for UK and Dutch managers. As Table VII shows, UK managers attributed significantly higher importance to managerial behaviour, personal qualities and organisational demand, while Dutch managers attributed significantly higher importance to environmental influence. However, the size of these effects was small and there was no significant difference in regard to the importance of leadership excellence. Interestingly there were no significant gender nor age differences within each country or between countries $(\mathrm{F}(5,1085)=2.10, \mathrm{p}=.064 ; \mathrm{F}(5,1086)=1.40, \mathrm{p}=.222$ respectively).

INSERT TABLE VII ABOUT HERE 


\section{DISCUSSION}

The above results show that the framework for Excellent Leadership developed by Selvarajah et al. (1995) is valid for both the Dutch and British context. The research results indicate that the five-factor structure is a sound representation of data, portraying reliable factors that are important to characterize Dutch and British HPMs. This suggests strong support for the first hypothesis.

Table VII gives an overview of the outcomes concerning the other hypotheses. As our approach concerned an exploratory study, for every hypothesis to be tested we have selected those value statements that, construct-wise, appeared to suitably cover the specific hypothesis. For example, Hypothesis 6 - Value statements which emphasise the strength of managers are equally important for the Netherlands and the UK, which are both characterized by a fairly, highly assertive culture - is best described by items EL1 "Have confidence when dealing with work and people", PQ5 "Deal calmly in tense situations", and 4 "Make decisions without depending too much on others". These items all refer to mangers who are confident in their work, and thus can be described as managers who are seen by employees as being strong in their managerial duties. Then for those items the loadings for the Dutch and British HPMS are compared, to evaluate whether the hypothesis should be accepted. If more than half of the value statements supported the hypothesis, it was accepted. In the case of hypothesis 6, although the loading on El1 differs between the two countries, the loadings on the other two value statements PQ5 and MB4 are equal and therefore hypothesis 6 is accepted.

\section{INSERT TABLE VIII ABOUT HERE}

From the nine hypotheses in Table VII five appear to be supported. Possible explanations for the rejected Hypotheses 2, 4 and 10 might be found in the work of Suutari (1996). Suutari (1996), specifically, categorised European countries, using the Ronen and Shenkar (1985) country clusters as a basis. Suutari placed the UK in the Anglo cluster (together with Ireland), while the Netherlands was categorised in the Nordic cluster (together with Sweden, Finland, and Denmark). As Suutari's research did not provide data for the Netherlands, but it did for Sweden, we take the corresponding scores for the latter country as a proxy for the Dutch scores. When looking at the scores for the UK and Sweden on the 14 scales developed by Suutari (1996), many scores appear to highly correspond. The largest differences can be noticed for the scales 'decision participation', 'individualized consideration', 'conflict management', and 'role clarification', where the UK scored higher than Sweden so, by proxy, than the Netherlands. 'Decision participation' comprises the extent to which a leader consults with subordinates, and allows them to participate in making decisions. As the Netherlands scored lower than the UK in this regard, managers in the Netherlands appear to be less willing to involve their employees in decision-making which could be seen as an indication of less respect. This is supported by the outcome on 'individualized consideration', i.e., the extent to which a leader treats each employee as an individual, and gives personal attention to each follower's needs and hopes, where the Netherlands again scored lower than the UK. In this sense, it is better understandable why hypothesis 2 ('Value statements which emphasise managers' respect for their employees are more important for the Netherlands, which is characterized by a rather feminine culture, than for the UK, which is characterized by a rather masculine culture') is not confirmed.

'Role clarification' concerns the extent to which a leader clarifies roles by making 
sure that the work group has clear rules, detailed job descriptions and clearly defined functions. As the Netherlands scored lower than the UK in the Suutari (1996) research, managers in this country tend less frequently to see a need to clarify roles compared with managers from the UK. This might explain the rejection of Hypothesis 4, ('Value statements which emphasise managers' preference for rules, procedures and formal systems are more important for the Netherlands, which is characterized by a medium level of uncertainty avoidance, than for the UK, which is characterized by a low level of uncertainty avoidance').

'Conflict management' is the extent to which a leader helps subordinates to resolve conflicts and quarrels among themselves and can be seen as a part of direct and effective communication. As the Netherlands scores lower than the UK, managers in this country have a lower need for eliminating conflict. This might partly explain the lack of confirmation for Hypothesis 10 ('Value statements which emphasise direct and straight-forward communicating managers are equally important for the Netherlands and the UK, which are both characterized by a highly performance-oriented culture').

To find a possible explanation for the rejection of Hypothesis 5 ('Value statements which emphasise managers' self-orientation are equally important for the Netherlands and the UK, which are both characterized by a highly individualistic culture'), we turn to the outcomes of the Globe project. This project distinguished ten culture clusters (Gupta et al., 2002), with the Netherlands being classified in the Germanic Europe group (together with Austria, Germany, and the German-speaking part of Switzerland) while the UK was categorised in the Anglo group (Together with Australia, the English-speaking part of Canada, Ireland, New Zealand, white-sample South Africa, and the USA). The German Europe group was characterised as having a high focus on participative leadership and cooperation between management and employees for the good of the organization (Szabo et al., 2002), in contrast to the Anglo group which was much more oriented toward individualistic performance (Ashkanasy et al., 2002). This could partly explain the lack of confirmation for Hypothesis 5 for the Dutch managers.

\section{LIMITATIONS, PRACTICAL IMPLICATION AND FURTHER RESEARCH}

The main limitation of this study lies in the fact that the findings are based upon reports from one single source; namely managers' perceptions. Hence, common-method effects may have inflated the correlations. The magnitude of such effects is subject to intense debate (Crampton and Wagner 1994; Podsakoff et al., 2003). However, most researchers agree that potential risks can be reduced by a careful questionnaire design (e.g., changes in the response format, anonymity, and encouraging participants' openness), which we paid specific attention to by testing the questionnaire beforehand among a small group of volunteers and by stressing specifically the anonymity of the survey.

The practical implication of the research is that multinational companies have to take the differences in HPM attributes into account when training their managers for oversees assignments. As managers cannot rely unconditionally on the attributes which made them successful in their home country, they need to be aware of the requirements put on them to become effective managers in another country, taking into account the attributes found in the research described in this article (Suutari, 1996; Bennett et al., 2000; Puck et al., 2008).

Additional research is needed in order to establish whether the five dimensions have predictive validity, for instance in terms of both managerial as well as organizational success. This should be done using a longitudinal design, in order to test causality. Multi-wave designs are especially useful in this regard, as they can provide more specific information about the stability of the measurement model and cross-lagged relationships between the 
factors of the Excellent Leadership framework and future success, subjective and objective, managerial as well as organizational, over time (De Lange et al., 2004).

An alternative strategy could be to perform a qualitative study to obtain further insight into the importance of the identified statements (items) in the light of future managerial and company performance. Another research opportunity is to extend the British data to other parts and sectors in the UK. This is especially important as there are indications that there exist multiple cultures within one country (Beugelsdijk et al., 2006; García-Cabrera and García-Soto, 2008).

\section{REFERENCES}

Alimo-Metcalfe, B. and Alban-Metcalfe, J. (2001). 'The development of a new Transformational Leadership Questionnaire'. Journal of Occupational \& Organizational Psychology, 74, 1-27.

Alimo-Metcalfe, B. and Alban-Metcalfe, J. (2005). 'The crucial role of leadership in meeting the challenges of change'. Vision, 9, 2: 27-39.

Arbuckle, J.L., and Wothke, W. (1999). AMOS 4.0 User's Guide. Chicago: Small Waters Corporation.

Alvesson, M. and Sveningsson, S. (2003). 'The great disappearing act: difficulties in doing leadership'. Leadership Quarterly, 14, 3: 359-381.

Armandi, B., Oppedisano, J. and Sherman, H. (2003). 'Leadership theory and practice: a "case" in point'. Management Decision, 41, 10: 1076-1088.

Ashkanasy, N.M., Trevor-Roberts, E. and Earnshaw, L. (2002). 'The Anglo cluster: legacy of the British empire'. Journal of World Business, 37: 28-39.

Bass, B.M. and Avolio, B.J. (1998). Manual for the Multifactor Leadership Questionnaire. Redwood: Mindgarden, Inc.

Bass, B.M. (2008). The Bass Handbook of Leadership: Theory, Research, and Managerial Applications. New York: Ruth Bass Free Press, $4^{\text {th }}$ ed.

Bedi, H. (1990). Understanding the Asian manager, Sydney: Allen \& Unwin.

Bennett, R., Aston, A. and Coiquhoun, T. (2000). 'Cross-cultural training, a critical step in ensuring the success of international assignments'. Human Resource Management, 39, 2/3: 239-250.

Bennis, W.G. (1983). The art of leadership, in: S. Srivastva (ed.), The executive mind, San Francisco: Jossey-Bass.

Bennis, W.G. (1989a). On becoming a leader, Reading: Addison-Wesley.

Bennis, W.G. (1989b). Why leaders can't read, Jossey-Bass: San Francisco.

Bennis, W.G. (1985), Leaders: the strategies for taking charge, New York: Harper and Row.

Berman, S.L., Phillips, R.A. and Wicks, A.C. (2005). 'Resource dependence, managerial discretion and stakeholder performance'. Academy of Management Proceedings: B1-B6.

Beugelsdijk, S., Van Schaik, T. and Arts, W. (2006). 'Toward a unified Europe? Explaining regional differences in value patterns by economic development, cultural heritage and historical shocks.' Regional Studies, 40, 3: 317-327.

Boehnke, K., Bontis, N. DiStefano, J.J. and DiStefano, A.C. (1999).Transformational leadership: an examination of cross-cultural differences and similarities. Working Paper, Richard Ivey School of Business, no. 050199

Boyacigiller, N.A. and Adler, N.J. (1991). The parochial dinosaur: organizational science in a global context. Academy of Management Review, 16. 2: 262-290.

Bret Becton, J. and Field, H.S. (2009). 'Cultural differences in organizational citizenship behavior: a comparison between Chinese and American employees'. The International 
Journal of Human Resource Management, 20, 8: 1651-1669.

Brodbeck, F.C., Frese, M., Akerblom, S., Audia, G., Bakacsi, G., Bendova, H. et al. (2000). 'Cultural variation of leadership prototypes across 22 countries'. Journal of Occupational and Organizational Psychology, 73: 1-29.

Burns, J.M. (1978). Leadership, New York: Harper and Row.

Burns, J.M. (1984). The power to lead, New York: Harper and Row.

Byrne, B. (2001). Structural equation modeling with AMOS: basic concepts, applications and programming, New Jersey: Lawrence Erlbaum.

Chatman, J.A. and Jehn, K.A. (1994). 'Assessing the relationship between industry characteristics and organizational culture: how different can you be?'. Academy of Management Journal, 37, 3: 522-553.

Conger, J.A. and Kanungo, R.N. (1987). 'Toward a behavioral theory of charismatic leadership in organizational settings'. Academy of Management Review, 12, 4: 637-47.

Crampton, S.M., and Wagner, J.A. (1994). 'Percept-percept inflation in micro-organizational research'. Journal of Applied Psychology, 79, 67-76.

Deal, T.E. and Kennedy, A. (1982). Corporate cultures: the rites and rituals of organizational life, Reading: Mass Addison-Wesley.

De Lange, A.H., Taris, T.W., Kompier, M.A.J., Houtman, I.L.D., and Bongers, P.M. (2003). 'The very best of the Millennium: Longitudinal research and the Demand-Control(Support) model'. Journal of Occupational Health Psychology, 8: 282-305.

Den Hartog, D.N., House, R.J., Hanges, P.J., Ruiz-Quintanilla, S.A., Dorfman, P.W. \& GLOBE Associates (1999). 'Culture specific and cross-culturally generalizable implicit leadership theories: are attributes of charismatic/transformational leadership universally endorsed?' The Leadership Quarterly, 10, 2: 219-256.

De Waal, A.A., Van der Heijden, B.I.J.M., Meyer, D. and Selvarajah, C. (2010). Characteristics of high performing managers in the Netherlands, submitted

Dickson, M.W., Den Hartog, D.N. and Mitchelson, J.K. (2003). 'Research on leadership in a cross-cultural context: making progress, and raising new questions'. The Leadership Quarterly, 14: 729/768.

Dorfman, P.W., Howell, J.P., Hibino, S., Lee, J.K., Tate, U. and Bautista, A. (1997). 'Leadership in Western and Asian countries: commonalities and differences in effective leadership processes across cultures', The Leadership Quarterly, 8, 3: 233-274.

Edwards, J.E., Rode, L.G. and Ayman, R. (1989). 'The construct validity of scales from four leadership questionnaires'. Journal of General Psychology, 116, 2: 171-181.

Endrissat, N., Mueller, W.R. and Meissner, J.O. (2005). 'What is the meaning of leadership? A guided tour through a Swiss-German leadership landscape'. Academy of Management Proceedings: A1-A6.

Fang, T. (2003). 'A critique of Hofstede's fifth national culture dimension'. International Journal of Cross Cultural Management, 3: 347-368.

Fey, C.F., Adaeva, M. and Vitkovskaia, A. (2001). 'Developing a model of leadership styles: what works best in Russia?'. International Business Review, 10: 615-643.

Gabrielsson, M., Darling, J. and Seristö, H. (2009). 'Transformational team-building across cultural boundaries, a case focusing on the key paradigm of leadership styles'. Team Performance Management, 15, 5/6: 235-256.

García-Cabrera, A.M. and García-Soto, M.G. (2008). 'Cultural differences and entrepreneurial behaviour: an intra-country cross-cultural analysis in Cape Verde'. Entrepreneurship \& Regional Development, 20: 451-483.

Gerstner, C.R. and Day, D.V. (1994). 'Cross-cultural comparison of leadership prototypes'. Leadership Quarterly, 5, 2: 121-134.

Gill, R. (2006). Theory and Practice of Leadership. Thousand Oaks: Sage Publications. 
Girlando, A.P., Anderson, C.J. and Zerillo, J.W. (2004). 'An examination of Hofstede's paradigm of national culture and its malleability: Italy and U.S. thirty years later'. Journal of Transnational Management, 10, 1: 23-36.

Graeff, C.L. (1983). 'The situational leadership theory: a critical view'. Academy of Management Review, 8: 285-291.

Groves, K.S. (2005). 'Linking leadership skills, follower attitudes and contextual variables via an integrated model of charismatic leadership'. Journal of Management, 31, 2: 255277.

Gupta, V., Hanges, P.J. and Dorfman, P.W. (2002). 'Cultural clusters: methodology and findings'. Journal of World Business, 37, 1: 11-15.

Hair, J. F., Anderson, R.E., Tatham, R.L. and Black, W.C. (1998). Multivariate Data Analysis, New Jersey: Prentice-Hall.

Hansen, G.S. and Wernerfelt, B. (1989). 'Determinants of firm performance: the relative importance of economic and organizational factors'. Strategic Management Journal, 10, 5: 399-411.

Harrison, G.L. and McKinnon, J.L. (1999). 'Cross-cultural research in management control systems design: a review of the current state'. Accounting, Organizations and Society, 24: 483-506.

Hazucha, J.F., Hezlett, S.A., Bontems-Wackens, S. and Ronnkvist, A. (1999). 'In search of the Euro-manager: management competencies in France, Germany, Italy and the United States'. In: Mobley, W.H., Gessner, M.J. and Arnold, V. (eds), Advances in Global Leadership, JAI Press, Stamford, CT.

Heifetz, R., Grashow, A. and Linsky, M. (2009). 'Leadership in a (permanent) crisis'. Harvard Business Review, July-August: 62-69.

Hernandez, M. (2008). 'Promoting stewardship behaviour in organizations: a leadership model'. Journal of Business Ethics, 80, 1: 121-128.

Hillman, A.J. (2003). 'Determinants of political strategies in US multinationals'. Business \& Society, 42, 4: 355-384.

Hoecklin, L. (1995). Managing cultural differences: strategies of competitive advantage. Addison Wesley Publishing Ltd.

Hofstede, G. (1980). Culture's Consequences: International differences in work-related values, Thousand Oaks: Sage Publications.

Hofstede, G. (2001). Cultures consequences: comparing values. Behaviours, institutions and organisations across nations, Thousand Oaks: Sage Publications.

Hofstede, G.J., Pedersen, P. and Hofstede, G. (2002). Exploring culture: exercises, stories and synthetic cultures, $1^{\text {st }}$ edition, Yarmouth, Maine: Intercultural Press.

Hollander, E.P. (1978). Leadership dynamics, New York: Free Press.

House, R.J. (1971). 'A path-goal theory of leader effectiveness'. Administrative Science Quarterly, 16, 321-338.

House, R.J., Wright, N.S. and Aditya, R.N. (1997). 'Cross-cultural research on organizational leadership: a critical analysis and a proposed theory.' In: Earley, P.C. and Erez, M. (eds), New perspectives on international industrial/organizational psychology (pp. 535-625), Jossey-Bass, San Francisco.

House, R., Javidan, M., Hanges, P. and Dorfman, P. (2002). 'Understanding cultures and implicit leadership theories across the globe: an introduction to project GLOBE'. Journal of World Business, 37: 3-10.

House, R. J., Hanges, P. J., Ruiz-Quintanilla, S. A., Dorfman, P. W., Javidan, M., and Dickson, M. (1998). Cultural influences on leadership: Project GLOBE. Paper presented at the 14th EGOS Colloquium, Maastricht, Holland.

House, R.J., Hanges, P.J., Javidan, M., Dorfman, P.W. and Gupta, V. (eds.) (2004). Culture, 
leadership, and organizations, the GLOBE study of 62 societies, Thousand Oaks: Sage Publications.

Hunt, J.G., and Larson, L.L. (1979). Crosscurrents in Leadership, Carbondale: Southern Illinois University Press.

Iguisi, O. (2009). 'Motivation-related value across cultures'. African Journal of Business Management, 3, 4: 141-150.

Javidan, M. and House, R. J. (2001). 'Cultural acumen for the global manager: lessons from project GLOBE'. Organizational Dynamics, 29, 4: 289-305.

Javidan, M. and Carl, D.E. (2004). 'East meets West: a cross-cultural comparison of charismatic leadership among Canadian and Iranian executives'. Journal of Management Studies, 41, 4: 665-691.

Jayakody, J.A.S.K. (2008). 'Charismatic leadership in Sri Lankan business organizations'. Journal of Management Development, 27, 5: 480-498.

Johnson, R.A. and Greening, D.W. (1999). 'The effects of corporate governance and institutional ownership types of corporate social performance'. Academy of Management Journal, 42, 5: 564-576.

Jong, M. de, Steenkamp, J.B.E.M. and Veldkamp, B. (2009). 'A model for the construction of country-specific yet internationally comparable short-form marketing scales'. Marketing Science, 28, 4: 674-689.

Juhl, H.J., Kristensen, K., Kanji, G.K. and Batley, T.W. (2000). 'Quality management: a comparison of cultural differences.' Total Quality Management, 11, 1: 57-65

Kantor, R.M. (1985). The change masters, London: Unwin.

Kerlinger, F. (1973). Foundations of behavioral research, New York: Holt Rinehart and Weiston.

Kerr, S., and Jermier, J.M. (1978). 'Substitutes for leadership: their meaning and measurement'. Organizational Behaviour and Human Performance, 22: 375-403.

Khatri, N. (2009). 'Consequences of power distance orientation in organizations'. Vision, 13, 1: $1-9$.

Kilmann, R.H., Saxton, M.J., Serpa, R. (1985). Gaining control of the corporate culture, San Francisco: Jossey-Bass.

Kirkman, B., Lowe, K. and Gibson, C. (2006). 'A quarter century of culture's consequences: a review of empirical research incorporating Hofstede's cultural values framework'. Journal of International Business Studies, 37: 285-320.

Kouzes, J.M. (2008). The Leadership Challenge, $4^{\text {th }}$ ed., New York: Jossey-Bass.

Laurent, A. (1983). 'The cultural diversity of Western conceptions of management'. International Studies of Management and Organizations, 8, 2: 75-96.

Lee, S.K.J. and Yu, K. (2004). 'Corporate culture and organizational performance'. Journal of Managerial Psychology, 19, 4: 340-359.

Lesley, J.B. and Van Velsor, E. (1998). A cross-national comparison of effective leadership and teamwork: toward a global workforce. Center for Creative Leadership, Greensboro, $\mathrm{NC}$

Ling, W. (1989). 'Pattern of leadership behaviour assessment in China'. Psychological: An International Journal of Psychology in the Orient, 32, 2: 129 -134.

Ling, W., Fang, L., Gao, J., and Khanna, A. (1992). 'The effect of different social groups on implicit leadership factors [in Chinese]'. Acta Psychologica Sinica, 2, 1: 43-49.

Marcoulides, G.A., Nathanael, P., Marcoulides, L.D. and Soteriou, A. (2004). 'Cross-national stability of a leadership model'. Psychological Reports, 94: 517-522.

Martin, H.J., Hunt, J.G. and Osborn, R.N. (1981). 'A macro-organizational approach to leadership'. Academy of Management Proceedings: 234-238.

Matic, J.L. (2008). 'Cultural differences in employee work values and their implications for 
management'. Management, 13, 2: 93-104.

McCoy, S., Galletta, D.F. and King, W.R. (2005). 'Integrating culture into IS research: the need for current individual-level measures'. Communications of the Association for Information Systems, 15: 211-224.

Mehta, R., Larsen, T., Rosenbloom, B., Mazur, J. and Polsa, P. (2001). 'Leadership and cooperation in marketing channels: a comparative empirical analysis of the USA, Finland and Poland.' International Marketing Review, 18, 6: 633-667.

Merchant, K.A. and Van der Stede, W.A. (2003). Management control systems Performance measurement, Evaluation and Incentives. Prentice Hall, New York

Mihm, J.C. (2004). Human capital: building on the current momentum to transform the Federal Government, GAO reports, GAO-04-976T, U.S.A.

Misumi, J. (1984). The Behavioural Science of Leadership, Tokyo: Yuhikaka.

Morrison, A.J. (2000). 'Developing a global leadership model'. Human Resource Management, 39, 2\&3: 117-131.

Murkhi, S.K. (1989). 'Leadership profiles of Malaysian and Australian managers', in: K. Inkson, B. Berg and P. Oliver (eds.), Proceedings of the Australian and New Zealand Association of Management Educators Conference, Auckland.

Northouse, P.G. (2009). Leadership: Theory and Practice, Sage Thousand Oaks: Sage Publications.

Palrecha, R. (2009). 'Leadership - universal or culturally-contingent - a multi-theory/multimethod test in China'. Academy of Management Proceedings: 1-6.

Pardey, D. (2008). 'Next generation leaders'. Strategic HR Review, 7, 3: 32-36.

Pascale, R.T. and Athos, A.G. (1981). The art of Japanese management, New York: Simon \& Schuster.

Peters, T.J. and Waterman, R.H. (1983). In Search of excellence: lessons from America's best-run companies, New York: Harper and Row.

Peztall, S., Selvarajah, C. and Willis, Q. (1991). Management: a behavioural approach, Melbourne: Longman Cheshire.

Picard, R.R. and Reis, P. (2002). 'Management control systems design: a metaphorical integration of national cultural implications'. Managerial Auditing Journal, 17, 5: 222233.

Podsakoff, P.M., Mackenzie, S.B., Lee, J.Y., and Podsakoff, N.P. (2003). 'Common method bias in behavioral research: a critical review of the literature and recommended remedies'. Journal of Applied Psychology, 88, 879-903.

Porter, M.E. (1980). Competitive strategy: techniques for analyzing industries and competitors, New York: Free Press.

Prigogine, I. (1984). Order out of chaos, New York: Bantam.

Puck, J.F., Kittler, M.G. and Wright, C. (2008). 'Does it really work? Re-assessing the impact of pre-departure cross-cultural training on expatriate adjustment'. International Journal of Human Resource Management, 19, 12: 2182-2197.

Robie, C., Johnson, K.M., Nilsen, D. and Hazucha, J.F. (2001). 'The right stuff: understanding cultural differences in leadership performance'. Journal of Management Development, 20, 7: 639-650.

Ronen, S. and Shenkar, O. (1985). 'Clustering countries on attitudinal dimensions: a review and synthesis'. Academy of Management Review, 10: 435-454.

Rost, J.C. (1991). Leadership for the twenty-first century, New York: Praeger.

Schriesheim, C.A. (1982). 'The great high consideration - high initiating structure leadership myth: evidence on its generalizability'. Journal of Social Psychology, 116, 2: 221-227.

Selvarajah, C. (2008). Dimensions that relate to excellence in leadership in Cambodia, Paper presented during the British Academy of Management conference, Harrowgate: UK. 
Selvarajah, C. and Meyer, D. (2007). 'Profiling the Chinese manager: exploring dimensions that relate to leadership'. Leadership \& Organization Development Journal, 29, 4: 359375.

Selvarajah, C. and Meyer, D. (2008). One nation, three cultures: exploring dimensions that relate to leadership in Malaysia, Working paper, Swinburne University, Australia.

Selvarajah, C., Duignan, P., Nuttman, C. and Suppiah, C. (1995). 'In search of the Asian leader: an exploratory study of dimensions that relates to excellence in leadership'. Management International Review: Journal of International Business, 35, 1: 29-34.

Sendjaya, S., Saroos, J.C. and Santora, J.C. (2008). 'Defining and measuring servant leadership behaviour in organizations'. Journal of Management Studies, 45, 2: 402-424.

Shao, L. and Webber, S. (2006). 'A cross-cultural test of the five-factor model of personality and transformational leadership'. Journal of Business Research, 59: 936-944.

Silverthorne, C. (2001). 'Leadership effectiveness and personality: a cross cultural evaluation'. Personality and Individual Differences, 30, 2: 303-309.

Sinha, J.B.P. (1980). The nurturant task leader: a model of the effective executive, New Delhi: Concept Publishing Company.

Smith, P.B., Misumi, J., Tayeb, M., Peterson, M. and Bond, M. (1989). 'On the generality of leadership style measures across cultures'. Journal of Occupational Psychology, 62: 97109.

Srivastva, S. (1983). The executive mind (edited), San Francisco: Jossey-Bass.

Stogdill, R.M., and Coons, A.E. (1957). Leader behaviour: its description and measurement, (Eds.), Research Monograph 88, Ohio State University, Columbus, OH.

Studer, Q. (2007). Results that last: hardwiring behaviors that will take your company to the top, New York: John Wiley \& Sons.

Suutari, V. (1996). 'Leadership ideologies among European managers: a comparative survey in a multinational company'. Scandinavian Journal of Management, 12, 4: 389-409.

Sweney, A.B., Fiechtner, L.A. and Samores, R.J. (1975). 'An integrative factor analysis of leadership measures and theories'. Journal of Psychology, 90, 1:75-84.

Swierczek, F.W. (1991). 'Leadership and culture: comparing Asian managers'. Leadership and Organisation Development Journal, 12, 7: 3-10.

Szabo, E., Brodbeck, F.C., Den Hartog, D.N., Reber, G., Weibler, J. and Wunderer, R. (2002). 'The Germanic Europe cluster: where employees have a voice'. Journal of World Business, 37: 55-68.

Takala, T. (1998). 'Plato on leadership'. Journal of Business Ethics, 17: 785-798.

Taormina, R. and Selvarajah, C. (2005). 'Perceptions of leadership excellence in ASEAN nations'. Leadership, 1, 3: 299-322.

Taras, V., Rowney, J. and Steel, P. (2009). 'Half a century of measuring culture: review of approaches, challenges, and limitations based on the analysis of 121 instruments for quantifying culture'. Journal of International Management, 15: 357-373.

Trompenaars, F. and Hampden-Turner, C. (2003). Riding the waves of culture, $2^{\text {nd }}$ edition, London: Nicholas Brealey Publishing.

Vroom, V. H. and Yetton, P.V.V. (1973). Leadership and Decision-Making, Pittsburgh: University of Pittsburgh Press.

Waal, A.A. de (2008). 'The secret of high performance organisations'. Management Online REview, April.

Xu, L.C., Chen, L., Wang, D., and Xue, A.Y. (1985). 'The role of psychology in enterprise management [in Chinese]'. Acta Psychologica Sinica, 1, 4: 339-345.

Yukl, G.A. (1989). Leadership in Organizations ( $2^{\text {nd }}$ ed.), Englewood Cliffs: Prentice-Hall.

Zagorsek, H., Jaklic, M. and Stough, S.J. (2004). 'Comparing leadership practices between the United States, Nigeria and Slovenia: does culture matter?" Cross Cultural 
Comparing Dutch and British high performing managers

Management, 11, 2: 16-34. 


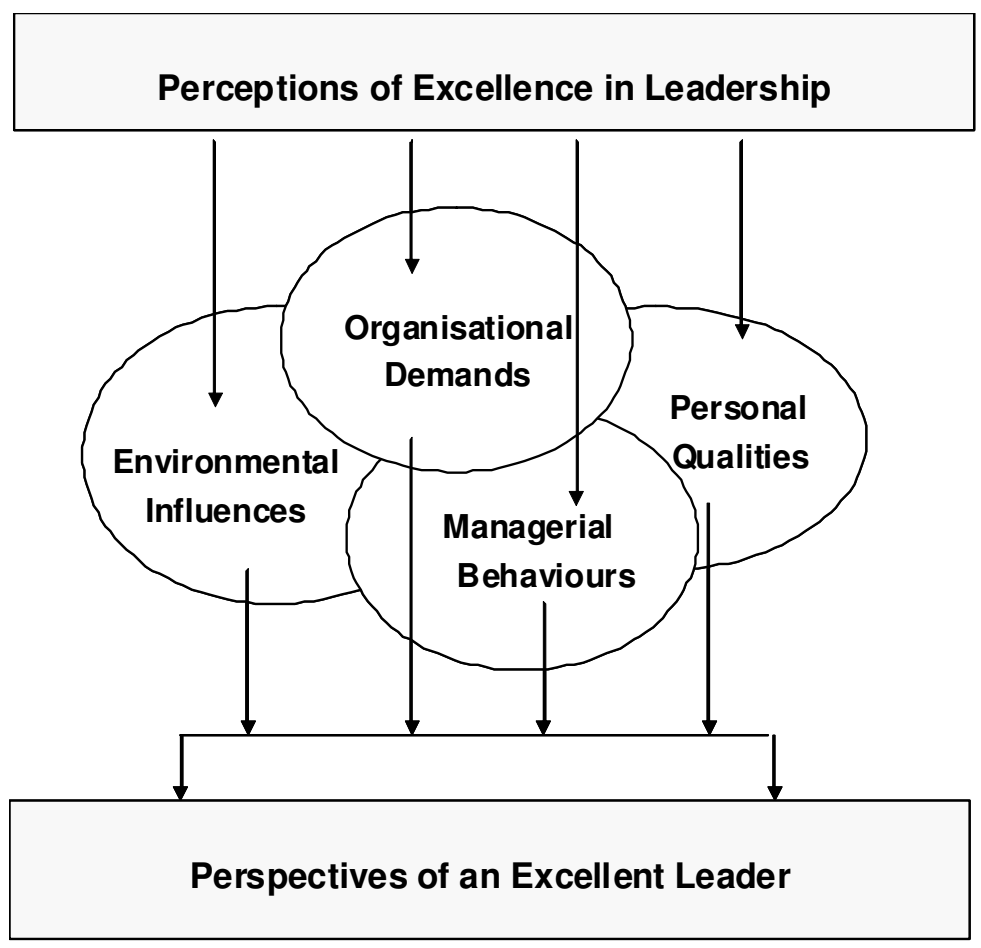

Figure 1: Conceptual Framework for the Study of Excellent Leadership (Selvarajah et al., 1995) 
Table I: Mean scores from the GLOBE project for the Netherlands and the UK

\begin{tabular}{|l|c|c|}
\hline Dimension & $\begin{array}{c}\text { Score for the } \\
\text { Netherlands }\end{array}$ & Score for the UK \\
\hline Assertiveness & 4.46 & 4.50 \\
\hline Future orientation & 4.72 & 4.13 \\
\hline Gender egalitarianism & 3.62 & 3.36 \\
\hline Humane orientation & 4.02 & 4.18 \\
\hline Performance orientation & 4.46 & 4.45 \\
\hline Power distance & 4.32 & 4.92 \\
\hline Institutional collectivism & 4.62 & 4.21 \\
\hline In-group collectivism & 3.79 & 4.22 \\
\hline Uncertainty Avoidance & 4.81 & 4.15 \\
\hline
\end{tabular}


Comparing Dutch and British high performing managers

Table II: Excellent Leadership items' factor loadings

\begin{tabular}{lcc}
\hline Value statement & $\begin{array}{c}\text { Loadings for } \\
\text { the } \\
\text { Netherlands }\end{array}$ & $\begin{array}{c}\text { Loadings } \\
\text { for the } \\
\text { UK }\end{array}$ \\
\hline $\begin{array}{l}\text { EL1. Have confidence when dealing with work } \\
\text { and people }\end{array}$ & .608 & .764 \\
EL2. Give recognition for good work & .631 & .701 \\
EL3. Create a sense of purpose and enthusiasm in & .630 & .765 \\
$\quad$ the workplace & & \\
EL4. Motivate employees & .560 & .815 \\
EL5. Continue to learn how to improve & .502 & .716 \\
$\quad$ performance & .446 & .461 \\
EL6. Have a strategic vision for the organisation & .026 & .075 \\
RMSEA & .994 & .973 \\
GFI & .994 & .979 \\
CFI
\end{tabular}


Comparing Dutch and British high performing managers

Table III: Environmental Influences Items' items' factor loadings

\begin{tabular}{lcc}
\hline Value statement & $\begin{array}{c}\text { Loadings for } \\
\text { the } \\
\text { Netherlands }\end{array}$ & $\begin{array}{c}\text { Loadings } \\
\text { for the } \\
\text { UK }\end{array}$ \\
\hline EI1. Have a multicultural orientation and approach & .604 & .711 \\
EI2. Identify social trends which may have an & .587 & .695 \\
$\quad$ impact on the work & & \\
EI3. Be socially and environmentally responsible & .548 & .771 \\
EI4. Be responsive to political realities in the & .342 & .457 \\
$\quad$ environment & & \\
EI5. Constantly evaluate emerging technologies & .280 & .458 \\
RMSEA & .015 & .025 \\
.GFI & .997 & .992 \\
CFI & .997 & .997 \\
\hline
\end{tabular}


Comparing Dutch and British high performing managers

Table IV: Personal Qualities items' factor loadings

\begin{tabular}{llcc}
\hline Factor with value statements & $\begin{array}{c}\text { Loadings for } \\
\text { the } \\
\text { Netherlands }\end{array}$ & $\begin{array}{c}\text { Loadings } \\
\text { for the } \\
\text { UK }\end{array}$ \\
\hline PQ1. & Respect the self-esteem of others & .565 & .688 \\
PQ2. Be consistent in dealing with people & .585 & .746 \\
PQ3. Accept responsibilities for mistakes & .515 & .702 \\
PQ4. Deal calmly in tense situations & .523 & .658 \\
PQ5. Be dependable and trustworthy & .566 & .770 \\
PQ6. Write clearly and concisely & .444 & .527 \\
PQ7. Listen to the advice of others & .454 & .643 \\
PQ8. Be an initiator, not a follower & .392 & .587 \\
PQ9. Have a sense of humour & .392 & .480 \\
PQ10. Follow what is morally right, not what is & .403 & .418 \\
& right for self or for the organisation & .034 & .074 \\
RMSEA & .983 & .934 \\
GFI & .970 & .942 \\
\hline
\end{tabular}


Table V: Managerial Behaviours items' factor loadings

\begin{tabular}{|c|c|c|}
\hline Factor with value statements & $\begin{array}{c}\text { Loadings for } \\
\text { the } \\
\text { Netherlands }\end{array}$ & $\begin{array}{c}\text { Loadings } \\
\text { for the } \\
\text { UK }\end{array}$ \\
\hline MB1. Make work decisions quickly & .523 & .658 \\
\hline MB2. Select work wisely to avoid overload & .506 & .497 \\
\hline $\begin{array}{l}\text { MB3. Make decisions without depending too much } \\
\text { on others }\end{array}$ & .465 & .385 \\
\hline MB4. Trust those to whom work is delegated & .401 & .612 \\
\hline $\begin{array}{l}\text { MB5. Listen to and understand the problems of } \\
\text { others }\end{array}$ & .453 & .595 \\
\hline MB6. Focus on the task-at-hand & .504 & .597 \\
\hline MB7. Delegate & .360 & .610 \\
\hline MB8. Persuade others to do things & .426 & .653 \\
\hline MB9. Keep up-to-date on management literature & .382 & .260 \\
\hline MB10. Be logical in solving problems & .441 &. .472 \\
\hline RMSEA & .054 & ,078 \\
\hline GFI & .971 & .935 \\
\hline CFI & .907 & .902 \\
\hline
\end{tabular}


Comparing Dutch and British high performing managers

Table VI: Organisational Demands items' factor loadings

\begin{tabular}{llcc}
\hline Value statement & $\begin{array}{c}\text { Loadings for } \\
\text { the } \\
\text { Netherlands }\end{array}$ & $\begin{array}{c}\text { Loadings } \\
\text { for the } \\
\text { UK }\end{array}$ \\
\hline OD1. Sell the professional or corporate image to & .626 & .686 \\
the public & & \\
OD2. Support decisions made jointly by others & .537 & .595 \\
OD3. Share power & .561 & .641 \\
OD4. Give priority to long-term goals & .395 & .503 \\
OD5. Focus on maximising productivity & .399 & .551 \\
OD6. Adjust organisational structures and rules & .332 & .439 \\
RMSEA realities of practice & & \\
RFI & .021 & .056 \\
CFI & .99 & .98 \\
\hline
\end{tabular}


Table VII: Comparison of Mean Values for Scales

\begin{tabular}{|c|c|c|c|c|c|c|c|}
\hline & Country & Mean & $\begin{array}{c}\text { Std. } \\
\text { Deviation }\end{array}$ & $\begin{array}{c}\mathrm{F} \\
(1,1092)\end{array}$ & $\mathrm{p}$-value & $\begin{array}{c}\text { Partial } \\
\eta^{2}\end{array}$ & $\begin{array}{l}\text { Cronbach's } \\
\text { alpha }\end{array}$ \\
\hline \multirow{2}{*}{$\begin{array}{l}\text { Organisational } \\
\text { Demand }\end{array}$} & Netherlands & 3.8315 & .48815 & \multirow[t]{2}{*}{6.479} & \multirow[t]{2}{*}{.011} & \multirow[t]{2}{*}{.006} & \multirow[t]{2}{*}{.66} \\
\hline & $\overline{\mathrm{UK}}$ & 3.9225 & .60013 & & & & \\
\hline \multirow{2}{*}{$\begin{array}{l}\text { Personal } \\
\text { Qualities }\end{array}$} & Netherlands & 4.2099 & .38051 & \multirow[t]{2}{*}{36.208} & \multirow[t]{2}{*}{.000} & \multirow[t]{2}{*}{.032} & \multirow[t]{2}{*}{.78} \\
\hline & UK & 4.3783 & .47338 & & & & \\
\hline \multirow{2}{*}{$\begin{array}{l}\text { Environmental } \\
\text { Influence }\end{array}$} & Netherlands & 3.7691 & .51436 & \multirow[t]{2}{*}{22.500} & \multirow[t]{2}{*}{.000} & \multirow[t]{2}{*}{.020} & \multirow[t]{2}{*}{.63} \\
\hline & UK & 3.5825 & .70892 & & & & \\
\hline \multirow{2}{*}{$\begin{array}{l}\text { Leadership } \\
\text { Excellence }\end{array}$} & Netherlands & 4.4282 & .42046 & \multirow[t]{2}{*}{2.983} & \multirow[t]{2}{*}{.084} & \multirow[t]{2}{*}{.003} & \multirow[t]{2}{*}{.76} \\
\hline & $\overline{U K}$ & 4.4819 & .53143 & & & & \\
\hline \multirow{2}{*}{$\begin{array}{l}\text { Managerial } \\
\text { Behaviour }\end{array}$} & Netherlands & 3.8438 & .48370 & \multirow[t]{2}{*}{29.004} & \multirow[t]{2}{*}{.000} & \multirow[t]{2}{*}{.026} & \multirow[t]{2}{*}{.75} \\
\hline & UK & 4.0308 & .55935 & & & & \\
\hline
\end{tabular}


Table VIII: Matching hypotheses with value statements for the Dutch and British HPMs

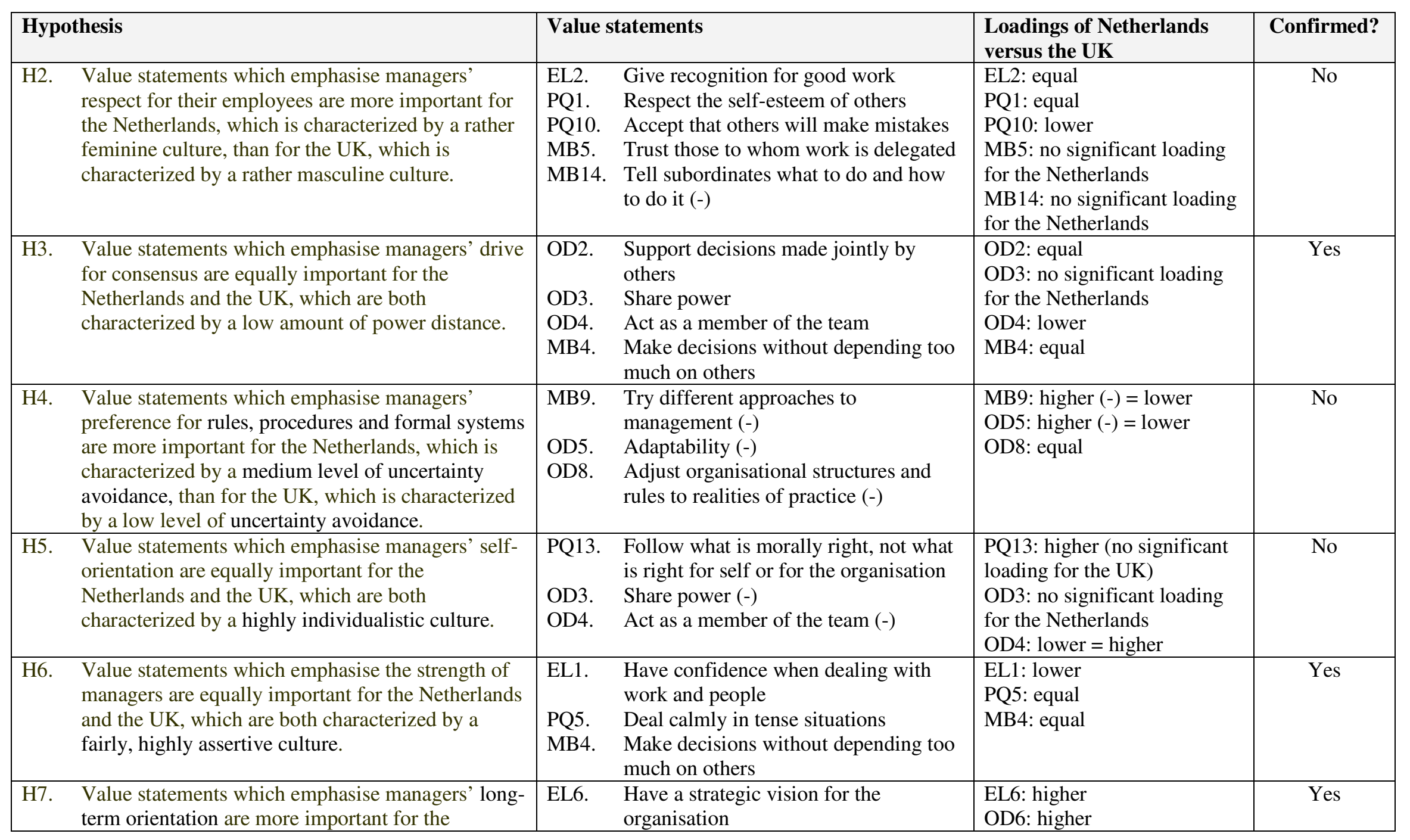




\begin{tabular}{|c|c|c|c|c|c|}
\hline & $\begin{array}{l}\text { Netherlands, which is characterized by a future- } \\
\text { oriented culture, than for the UK, which is } \\
\text { characterized by a less future-oriented culture. }\end{array}$ & OD6. & Give priority to long-term goals & & \\
\hline H8. & $\begin{array}{l}\text { Value statements which emphasise the flexibility } \\
\text { and adaptiveness of managers are more important } \\
\text { for the Netherlands, which is characterized by a } \\
\text { future-oriented culture, than for the UK, which is } \\
\text { characterized by a less future-oriented culture. }\end{array}$ & $\begin{array}{l}\text { EI7. } \\
\text { OD5. } \\
\text { OD8. } \\
\text { MB9. } \\
\text { MB11. }\end{array}$ & $\begin{array}{l}\text { Constantly evaluate emerging } \\
\text { technologies } \\
\text { Adaptability } \\
\text { Adjust organisational structures and } \\
\text { rules to realities of practice } \\
\text { Try different approaches to } \\
\text { management } \\
\text { Keep up-to-date on management } \\
\text { literature }\end{array}$ & $\begin{array}{l}\text { EI7: higher (no significant } \\
\text { loading for the UK) } \\
\text { OD5: equal } \\
\text { OD8: higher } \\
\text { MB9: higher (no significant } \\
\text { loading for the UK) } \\
\text { MB11: higher (no significant } \\
\text { loading for the UK) }\end{array}$ & Yes \\
\hline H9. & $\begin{array}{l}\text { Value statements which emphasise managers' } \\
\text { ability to create a family-like organisational culture } \\
\text { are equally important for the Netherlands and the } \\
\text { UK, which are both characterized by a medium } \\
\text { humane-oriented culture. }\end{array}$ & $\begin{array}{l}\text { EL3. } \\
\text { EI1. } \\
\text { EI4. } \\
\text { MB2. } \\
\text { OD4. }\end{array}$ & $\begin{array}{l}\text { Create a sense of purpose and } \\
\text { enthusiasm in the workplace } \\
\text { Have a multicultural orientation and } \\
\text { approach } \\
\text { Be socially and environmentally } \\
\text { responsible } \\
\text { Select work wisely to avoid overload } \\
\text { Act as a member of the team }\end{array}$ & $\begin{array}{l}\text { EL3: equal } \\
\text { EI1: equal } \\
\text { EI4: equal } \\
\text { MB2: no significant loading } \\
\text { for the Netherlands } \\
\text { OD4: lower }\end{array}$ & Yes \\
\hline
\end{tabular}

Note 1: (-) denotes that the loading for this specific value statement illustrates the opposite of the specific hypothesis

2: when the difference between the loadings for the Netherlands and the UK is $<0.1$, the scores are denoted to be equal 